ALVIN O. THOMPSON

\title{
SYMBOLIC LEGACIES OF SLAVERY IN GUYANA
}

\section{INTRODUCTION}

In 2005 the Roosevelt Study Center and other organizations in the Netherlands sponsored an international conference entitled "Conference on Slavery from Within." The conference brought together some of the leading scholars from the Americas and Europe to discuss the perception of slavery and its legacy in the Americas, largely through the eyes of persons living within the hemisphere and, more particularly, as the subtheme of the conference indicated, "New World Slavery Compared from an Enslaved Perspective." The hosting of the conference is symptomatic of new trends in the historiography on slavery in the Atlantic World during the last four decades or so.

With few exceptions, up to the 1960s (and to some extent up to the present) governments and political organizations in Europe and the Americas acted as though slavery was a secondary and largely-to-be-forgotten aspect of the development of the New World empires. Richard Price (2001:60) notes that "the silencing of the past has been endemic," while Livio Sansone (2001:86) writes about "the exorcism of slavery out of the pantheon of cultural production." Although the legacies of slavery - cultural, symbolic, psychological, and otherwise - were quite evident and pervasive throughout the postslavery societies, only relatively few state authorities and nongovernmental organizations paid any attention to them. The relatively few persons who paid serious attention to them were like voices crying in the wilderness.

However, the slavery past simply would not go away or remain muted forever. Increasingly, with the independence of African and Caribbean countries that were most directly and deeply affected by the slave trade and slavery, there has been renewed attention for this subject. Nationalists in the new postcolonial states, and a vocal minority of Blacks and Whites in other countries in which the Black diaspora is resident, have sought to resurrect

1. On the silence in Brazil, which boasts the second-largest Black population after Nigeria, see dos Santos Gomes 2001.

New West Indian Guide / Nieuwe West-Indische Gids vol. 80 no. 3 \& 4 (2006):191-220 
the slavery past. They have insisted that New World societies can only be fully understood by an intelligent (intellectual) appraisal of the impact of the transatlantic slave trade and slavery on both the sending and host communities. In recent years a fillip has been given to their endeavors through the UNESCO Slavery Route Project (inaugurated in 1994), which includes research on the general impact of the slave trade, and attempts to identify (and in some instances to retrieve) archival materials, and restore forts and other structures connected with the traffic in human beings. ${ }^{2}$

Some years before the UNESCO initiative, several governmental and nongovernmental organizations began to establish various institutions for the study of New World slavery and to erect monuments in honor/memory of the enslaved persons as a whole, or of particular groups or individuals. In Europe, also, several initiatives were taken in the last two decades, especially by the main slave-trading nations, to focus attention on the slave trade and slavery. While the governments of these countries have refused so far to endorse the view that the slave trade constituted "a crime against humanity," and while they have balked on the issue of reparations, they have contributed to the financing of studies on slavery, including the establishment of museums and libraries, and the hosting of exhibitions. Perhaps the most well known of these initiatives is the Liverpool Maritime Museum (opened in 1980), a section of which is dedicated to artefacts concerning the slave trade. Other important museums featuring the slave trade exist in Hull and Bristol. In the Netherlands, more recently, a project known as "The Atlantic World and the Dutch," sponsored partly by the Dutch government and partly by private organizations, has been initiated. An important part of that project involves the study of the transatlantic slave trade in all its varied impacts.

As for the Americas, in the United States, in particular, a number of museums, libraries, and slavery sites have been established or rehabilitated, and Black Studies programs have been initiated in several larger universities. The National Underground Railroad Freedom Center is the major project attracting federal government funds, in association with funds from the private sector (Blakely 2001:102-3; see also Drescher 2001:109-12). However, Allison Blakely (2001:102) views these developments as largely "symbolic remorse" by the dominant White group. In other parts of the Americas such activities have been more modest, partly because of financial constraints, and partly because the Black intelligentsia have been either too steeped in "things European" or were not sufficiently well organized to undertake them. A plethora of small organizations and groups have emerged in the various countries, often operating on their own and sometimes in conflict with each

2. In 1998 UNESCO also declared August 23 (1791), the date marking the beginning of the slave revolt in Haiti (St. Domingue), which led to the end of slavery and colonialism in that country, the International Day for the Remembrance of the Slave Trade. 
other about the main objectives that they should pursue and strategies they should adopt. Nevertheless, these groups have collectively helped to resurrect the slave past and place it, if not on the front burner, at least within the mainstream of intellectual thought.

Various groups engage in a wide range of cultural and symbolic representations of the legacies of slavery in the Americas. Within the Caribbean and some areas of the diaspora, perhaps the most well known of these are the Rastafarians (though, curiously enough, their chief iconic figure, the late Haile Selassie I, was emperor of Ethiopia rather than of any country that experienced the horrors of the transatlantic slave trade on any significant scale).

Haiti, the only country in the Americas that abolished slavery entirely through the action of the enslaved, stood as the lone exception for well over a century in relation to the emphasis on "things African." Noirism, as some scholars dubbed the Haitian Black ideology, had to fight a dogged battle against those who insisted that the slave past was just that: a thing of the past that should not be resurrected or kept alive. However, François ("Papa Doc") Duvalier, president of that country (1957-1971), erected a statue to the Black Maroon, regarded by Haitians as the chief symbol of their struggle for independence, freedom, and dignity. Since that time a number of other countries have erected statues or other symbolic representations in honor of their enslaved ancestors. Statues or busts, for instance, have been erected in Brazil to Zumbi of Palmares, Jamaica to Grandy Nanny ("Granny Nanny," Nanny of the Maroons), Barbados to Bussa, the Dominican Republic to Sebastian Lemba, and Guyana to Cuffy (Kofi) and Damon. A much larger number of symbolic representations have emerged in every country in which the Black presence in the Americas became significant (and in several instances not very significant) - Cuba, Belize, Honduras, Ecuador, Martinique, Venezuela, Colombia, Panama, Mexico, etc. (Price 2001:59-61; Thompson 2006:4-5).

Viewed in this wide context, the symbolic representations/expression of the legacies of slavery in Guyana are somewhat more understandable. However, the nationalist government in Guyana under Forbes Burnham went much further than any other government in the Americas in using the slavery past as its ideological foundation.

\section{GEOGRAPHICAL AND HISTORICAL BACKGROUND}

Guyana comprised two Dutch colonies, Berbice and Essequibo, during the seventeenth and eighteenth centuries. Around the mid-eighteenth century the boundaries of the latter colony were extended to include Demerara, which lay to its east, and by the end of the century Demerara had outstripped Essequibo in both population size and the quantity of sugar produced. The Dutch also shifted the headquarters of the colony from Essequibo to Demerara. The 
British captured the two colonies, Berbice and Demerara-Essequibo (for the third time) in 1803, and retained them in the Treaty of Paris in 1814, which brought an end to the Napoleonic Wars. In 1831 the colonies were amalgamated into one under the name British Guiana, by which it was known until it achieved independence in 1966, under the new name of Guyana.

Guyana, though consisting of a land mass of 214,969 square kilometers, was never a large-scale plantation enterprise in comparison, for instance, to Cuba, Haiti, Brazil, and the southern United States. Nevertheless, it possessed as draconian a slavery system as any of these countries, and arguably slavery left as indelible marks on its body politic as in most other places in the Americas. This can be seen today in the nature of its economy, which is almost completely agrarian; its concentration on sugar as the main export crop; its heavy emphasis on cash (export) crops rather than food crops; the location of its population almost completely along the coast and the lower reaches of the two main rivers (Berbice and Demerara), precisely in those areas that the slaveholding interests had opened up to produce sugar and coffee; and its infrastructure of dikes, sea defenses ("sea walls"), and mud dams, which were all typical of Dutch and British enterprise during the slavery period.

While the population has changed significantly since the end of slavery, in several respects race relations were similar to what existed during the slavery period. Today there is only a small European segment, and there are large African and East Indian segments. The East Indians were introduced immediately after the end of slavery as indentured workers to meet planter needs for a large labor force, consequent on the departure of a significant number of Africans to other parts of the country. The Indians fitted into basically the same physical structure of the plantation economy that the Africans had vacated, were given almost the same allowances, worked as hard, and were treated as less than human.

The introduction of the East Indians resulted in conflicts between them and the Africans (often referred to as Creoles in the early postslavery period). The Whites orchestrated these conflicts carefully in order to exploit both groups and maintain what they perceived as necessary security in the colony. This was done partly through keeping the groups physically apart as far as possible, and partly through stereotyping them. Unfortunately, these oppressed groups adopted the White stereotypes of each other (and sometimes of themselves). For instance, the Whites viewed the East Indians as clannish and unwilling to integrate into the wider society. At the same time, the Whites viewed them as hardworking and claimed that they had saved the sugar industry from collapse and the colony from the financial ruin that the Blacks had threatened through their laziness, idleness, and greed for unreasonably high wages (Williams 1991:148, 163-6; Thompson 1997:217-21; Moore 1999:141-56). In the early postindentureship period, though Blacks 
and Indians experienced increasingly greater contacts with each other, they nevertheless performed largely different occupational roles (Moore 1999:156; see also Despres 1969:40; Williams 1991:150).

Dale Bisnauth (2000:187) claims that up to around 1930 the East Indians were largely indifferent to what was happening in the wider society and only began to take an active interest in politics from then on. Blacks, of course, had begun to take an interest in politics in the late nineteenth century, though they were thwarted in their political aspirations by the White and Colored groups. In the post-World War II period, when the British initiated the first major efforts at democratization of the political process, Blacks and Indians began to jostle for political space and precedence, though for a decade or so this was largely restrained through the emergence of the PPP as the major political party, in which Cheddi Jagan and Forbes Burnham were the principal leaders. However, when the political break between them occurred in 1957, the contest for power broke out openly. As Robert Moore (1997:157) states,
in the early 1960s, as Guyana approached independence, Indians and blacks came into conflict over who would inherit the British mantle of government. The conflict in some parts of the country became intense and brutal. What was very significant was how the old, distinctly derogatory, stereotypes given a twentieth century veneer were brought forth to justify each side's hostility to the other.

Though not all agree that this conflict should be regarded as a legacy of slavery, within Guyana it is clearly viewed as such. The issue as to who suffered most and on whose blood and sweat the country was mainly built assumed prominence during the struggle for political power (Bartels 1977:401; Williams 1991:160). Largely muted in the early postindentureship period, it became prominent in the postwar years. ${ }^{3}$ Afro-Guyanese were quite sure that they had suffered for a much longer period, had to excavate millions of tons of earth to lay the foundations for the plantations from the mid-seventeenth century, and continued to be exploited in the postemancipation period. They argued, also, that it was their money that helped to subsidize Indian immigra-

3. Controversially, Thomas (2004:15) asserts, that "current processes of globalization have reinscribed racial and cultural hierarchies within and between nations, communities, and regions in ways that recall the centrality of racial categorization and racism to processes of modernization, nationalism, and state formation." However, most writers on Guyana are likely to take issue with this viewpoint, and argue that racism was muted at certain periods in the history of that country, was always just below the surface, and simply needed a catalyst (found in the political arena in the postwar period) to bring it to the surface once again. 
tion, and that the Indians undercut their efforts to secure a better deal from the Whites.

Thus many Afro-Guyanese see themselves as the natural inheritors of the country's political and economic kingdoms because of the sufferings of their ancestors. In 2000 David Hinds stated unequivocally that the sufferings that Afro-Guyanese underwent during slavery and beyond, and their "tremendous contribution ... in humanizing, nurturing, and holding Guyana together ... must always guarantee them a permanent role in the governance of the country." To be fair, he makes it clear that his comment refers to power-sharing rather than domination by any ethnic or other group: "As is the case with other races, there is no Guyana without the African-Guyanese. That's why those politicians in the PPP and the PNC who in the name of 'Majoritarian-Winner-take all Democracy' try to deny them their place at the table of governance are flying in the face of history and risking trouble"; and again, "The Indian in Guyana has not robbed the African of anything; the African has robbed himself/herself." 4 Still, a number of Afro-Guyanese saw nothing wrong with the PNC's rigging of several elections to keep Blacks in power (or Indians out of power). They intensely resented what they viewed as President Desmond Hoyte's capitulation to pressure, particularly from the United States, to hold ostensibly fair elections in which voting largely along racial lines was likely to ensure that the predominantly Indian PPP would capture and remain in power indefinitely.

Indians, on the other hand, emphasized that they had suffered at least as much as the Blacks, if for a shorter period, that they also rolled back tons of mud and in other ways felt the exploitative hands of colonialism and racism, that they saved the colony from ruin, and that these factors gave them a preferential right to run the country (Williams 1991:163-5, 171-2; Thompson 1997:219). Many of them accept Hugh Tinker's view that Indian indentureship constituted a new system of slavery (Tinker 1974). ${ }^{5}$ Janet Jagan, (American) wife of Cheddi Jagan and the person whom a number of scholars believe was the real ideological mind of the People's Progressive Party (PPP), at least in its formative years, asserted boldly that "indentureship was another form of slavery. In many aspects, it was equally brutal [as African Caribbean slavery]." 6

4. David Hinds, 2000, Emancipation and the African-Guyanese Reality. http://www. guyanacaribbeanpolitics.com/commentary/hinds_080200.html. Accessed April 8, 2005.

5. See also Moses V. Nagamootoo, Fruit of African Resistance and Sacrifies, Guyana Chronicle, August 3, 2003.

6. Eternal Glory to our Ancestors by the PPP, 1989, p. 1. For a rejection of the view that indentureship was a form of slavery see C.R.B. Edwards, "Slavery and Indentureship Were Not Similar in Nature," Stabroek News, May 19, 2002. It is important, however, to heed the warning of Seymour Drescher (2001:112), in the context of the debate on United States slavery, that "there is always a temptation for some to argue as though one could arrive at a hierarchy of collective suffering or radical evil so that only one such process reaches the apogee of uniqueness." 
Although contemporary Afro-Guyanese also often dubbed the newcomers the "new slaves," today they generally reject the idea that indentureship replicated the conditions of New World slavery. The statement by Cheddi Jagan and his followers that democracy was restored to Guyana on October 5, 1992, when the PPP came to power for the first time since independence, rubs salt into the wounds of these Blacks. It was also alleged that in a speech in Canada on October 30, 1996, Cheddi Jagan declared that "Black people are at the lowest scale of the social ladder."7

\section{COMPETING IDENTITIES}

Many present-day Afro-Guyanese have sought to reinterpret their history, especially their resistance to enslavement, in nationalist and/or ideological terms. However, while Indians generally view themselves as "nationalists," or committed to national development, they are slow to embrace an ideology that places Black/African slavery at its center. Deborah Thomas (2004:3) refers to the competing identities of "Blackness, Africanness and Jamaicanness" in forging a national identity that all Jamaicans locally and within the diaspora could embrace. Arguably, the main social divisions among Jamaicans are those of class and color; among Guyanese there is also the division of ethnicity. Although Guyanese view non-Guyanese as "foreigners," most of them still hold strongly to their ethnic identities. It might even be argued that for some of them ethnicity is primary among their competing identities. Guyana is, of course, unlike Jamaica, in that over 90 percent of Jamaicans trace their ethnic roots directly or indirectly to Africa, whereas about 50 percent of Guyanese trace theirs to India, and a little over 30 percent to Africa. Thus, instead of referring simply to "Guyanese," scholars often refer to "Indo-Guyanese" and "Afro-Guyanese," or to "East Indians" and "Africans" in Guyana. Given the added competition for economic, social, cultural, and political space, the implications for disunity are enormous.

Hamilton Green, former prime minister under the People's National Congress (PNC) government and now mayor of Georgetown, the country's capital, declared that slavery was the most significant and pervasive event in the life of the nation and that "all other events that followed explain contemporary Guyana." "Colonial heroes such as William Wilberforce and Fowell Buxton (British antislavery campaigners), and Sir Benjamin D'Urban (governor in the early 1830s) have been replaced by Cuffy (Kofi, leader of the 1763

7. "President Not Surprised at PNC Fuss," Guyana Chronicle, November 19, 1996. See also Gibson 2003:40, 42.

8. "Colonial Slavery was the Most Significant, Pervasive Experience - Says Mayor Hamilton Green," Guyana Chronicle, August 3, 2000. 
Berbice revolt), Quamina (a deacon in Le Resouvenir Church presided over by Rev. John Smith and one of the leaders of the 1823 Demerara revolt), and Damon (leader of the 1834 Essequibo revolt, the last servile revolt in the colony). The dome of the Guyana Bank for Trade and Industry (GBTI), on Water Street, Georgetown, houses a very interesting mural, completed in June 1974, when the bank was called Barclays. The mural pays homage to several persons who played seminal roles in the country's political, social, medical, and labor history, and includes not only some colonial officials, but also Cuffy and Quamina. While the latter is dubbed a "Slave-Deacon, Passive Resister," the caption relating to Cuffy's image is titled "Slave, Rebel, Diplomat, Visionary" (see Figure 1, p. 201). ${ }^{9}$ National monuments have been erected in honor of Cuffy and Damon, while Murray Street (named in honor of a British governor) in Georgetown has been renamed Quamina Street. Cuffy has officially been declared a national hero, as is the case with Zumbi of Palmares in Brazil, Gaspar Yanga in Mexico, and Grandy Nanny in Jamaica. In Guyana, the government under Forbes Burnham (the prime minister who led the country to independence and later declared the country a republic) decided virtually to forget Independence Day (May 26, 1966) as a day of national significance, and to focus attention on Republic Day (February 23, 1970), the same day on which the Berbice revolt, which Cuffy led, is deemed to have commenced (though he did not actually initiate the revolt). ${ }^{10}$

It remains a matter of conjecture as to why Burnham chose to focus on the 1763 revolt rather than on any other circumstance or event to ground his own "revolution." He might have chosen "scientific socialism," but a number of persons believe that he was not a genuine socialist. Cheddi Jagan, who became his archrival, dubbed his economic philosophy "state capitalism" parading as "scientific socialism." Others attribute to him a keen sense of history, an understanding of the connection between the past and the present, and intuition that slave iconography would become a major aspect in reconstructing the hemisphere's historical past. Burnham's supposed insight and radicalism were displayed not only in this regard, but also in relation to his firm embrace of the Non-Aligned Movement, and his permission to Cuba to transship troops to Angola, in the fight against the apartheid regime in South Africa. Finally, Burnham might have taken his cue from Fidel Castro, already an iconic figure in Latin America and the Caribbean, who linked his own revolution with "The 26th of July Movement" (the date of his assault on

9. http://www.gbtibank.com/art_dome_murals.html. Accessed April 20, 2006.

10. One of the inaccuracies (some would say "myths") that have crept into nationalist discourse on Cuffy is that he was on Magdalenenburg plantation when the revolt started on February 23. Actually, that plantation was on the Canje River, a tributary of the Berbice River. Cuffy lived on Lilienburg plantation on the Berbice River; the revolt on that river started a few days later (see Thompson 1987:156-58). 
Fulgencio Batista's regime, at the Moncada Barracks). Burnham might well have wished to ground his own "revolution" in a national date and circumstance of some historic significance.

P.H. Daly, a well-known nationalist historian, sees the "February Revolution" of 1763 as the ideological cornerstone on which the Cooperative Republic of Guyana was laid. According to him, "the co-operative revolution is the inevitable extension of the February Revolution to the economic level"; and again, "the Co-operative Revolution is the real challenge handed down to the independent nation of Guyana by the leaders of the February Revolution" (Daly 1970:86). Republicanism, opined Daly, was the logical outcome of the emancipation process, since it implied not only the overthrow of colonial slavery but all vestiges of colonialism. It was a fundamental psychological break with the fettered past, symbolized in British monarchism (Daly 1970:91).

T. Aston Sancho, at that time a PNC member of Parliament, gave the widest interpretation to the 1763 revolt, asserting that it not only preceded the Haitian Revolution but pointed the way toward that revolution and, by implication, to liberation in the Caribbean. In his words:

\begin{abstract}
With the rebellion the first flicker of light glowed across a dark frontier. The beams of its light gleam[ed] brighter in the deeds of the Haitian Revolution, in the eyes of Toussaint L'Overture [sic] and his men. Toussaint and his men understood perfectly dialectics and the science of revolution. But it is the Berbice Rebellion that points the way ... The ashes always smouldered. It became a flaming torch with this Independence we, their heirs, have gained ... They were the first slaves who from the midst of the filth and misery in which they lived dreamt of Independence. (Sancho 1966:12) ${ }^{11}$
\end{abstract}

This interpretation of the revolt became the standard or official one during the Burnham regime. He, himself, declared that the "revolution" was the "forerunner" to what followed in Haiti (Burnham 1970:69). ${ }^{12}$ It has become quite popular among the modern-day admirers of Cuffy to refer to his aborted revolt as a "revolution." 13

The citation of Cuffy in the GBTI's mural, referred to above, includes the description:

11. Buying into the mythology of the broad significance of the 1763 revolt, Eusi Kwayana (1999-2000:17) writes that "Thompson almost timidly confines the Berbice uprising to Berbice. Our historians should not be shy of making global judgments, even though new information may cause these to be modified."

12. Ovid Abrams (1998:34) referred to the revolt as "the first major revolution by Africans in the Western Hemisphere."

13. See, for instance, Burnham 1970:68; Abrams 1998:34. 
Sensitive and imaginative, blessed with a diplomat's shrewdness and a statesman's vision, he planned to set up an independent state in Upper Berbice, conceived in protest and dedicated to the proposition that all men were created free. Frustrated in 1763, his dream was fulfilled in 1966 when Guyana became independent and thus completed the job he began. In 1970 he was declared Guyana's first national hero and the honour denied him in life was paid to him two centuries after his death. ${ }^{14}$

Cuffy's Monument (statue and plinth) stands about 10 meters tall, along Vlissingen Road, one of the main thoroughfares in Georgetown, about 800 meters from the National Cultural Center, 400 meters from the Botanical Gardens and National Zoo, and a shorter distance from the official residence of the president. Designed by Guyanese sculptor Philip Moore, it is officially called "The 1763 Monument," but it is widely recognized in the country as a monument in honor of Cuffy.

It is important to elaborate how the image of Cuffy in statuary and other forms is being used today, especially among Afro-Guyanese, as a reference to all things that are deemed noble in the struggle for dignity, progress, development, and positive self-image. On Republic Day, Afro-Guyanese organize celebrations to commemorate the "revolutionary" struggle of this iconic figure. Actions that some scholars formerly regarded as flaws in Cuffy's character have been explained away or reinterpreted in positive ways. His letters to Governor Van Hoogenheim of Berbice offering to divide the colony between the Whites and those Blacks who chose to identify with the revolt have been reinterpreted as attempts to achieve a negotiated resolution through compromise rather than strife (Daly 1970:21, see also pp. 33-34). He is therefore seen as representative of the spirit of compromise that Guyanese are exhorted to seek in order to resolve the many political, social, cultural, and racial problems that periodically beset the nation, especially since the 1960s.

P.H. Daly has interpreted Cuffy's rape of a White woman whom the insurgents had captured as an act of retribution for the rape of Black women by their White overlords during slavery, rather than as an attempt to gratify his sexual desires. In Daly's (1970:47) words, "thus the derogatory weapon of the triumphant underdog went into action. And thus sex in the Revolution was used penally. And thus the moral defilement of African women by white men for centuries was throbbed back into them, full measure, pressed down, running over and overflowing." 15 Thus he attempts to sanitize this deed by the revolutionary leader.

14. http://www.gbtibank.com/art_dome_murals.html (accessed April 20, 2006). The view of Cuffy as a "warrior-statesman" and a "psychological strategist" had been promoted a few years earlier in Daly 1970:20, 26, 61-64.

15. See also Daly 1970:19, 20, 38; Paul N. Tennassee, "The Race Problem 1965-1992: Part II: The Post Independence Era: Alienation and Insurrection." http://www.guyanajournal.com/race2_pt.html. Accessed April 2, 2005. 
The physical image of Cuffy has also been enhanced or "rehabilitated" considerably in some instances. Although no image of how he actually looked exists, we can be reasonably certain that his clothing and general appearance resembled those of the typical enslaved man. However, in 1970 when the Guyana government under Burnham minted a silver coin to commemorate the founding of the Cooperative Republic it bore an image purported to be that of Cuffy. This image showed him with a beautifully cultured beard, something inconceivable for the typical enslaved man in Guyana at that time. In Vere T. Daly's book (1974:88) he is depicted as a bodybuilder, his upper body rippling with muscles, though much less so on his thighs and legs. However, in P.H. Daly's book (1970:60) his general bearing is much closer to what we would expect of the average enslaved man. The GBTI's image of him is even more questionable. Here, he is depicted in immaculate clothing, which includes a white, long-sleeved, decorated shirt, blue trousers tucked at the knee into long golden-brown boots, a leather belt around his waist with a golden belt buckle, and a sword in a scabbard at his left side.

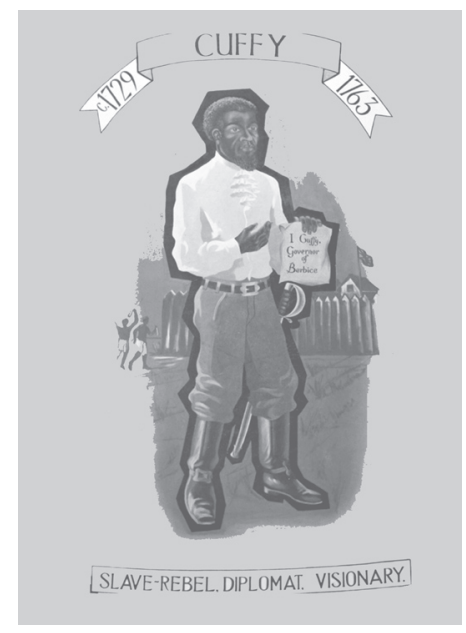

Figure 1. Cuffy in GBTI's Dome

The much more well-known bronze statue (the main part of the 1763 monument) of Cuffy depicts an individual that does not really represent an enslaved person, and most will probably agree that it does not portray an image of any living being (see Figure 2, p. 202). It is a highly imaginative work, and seems to depict forms of gods that are widely represented in African, Asian, and Native American art. But, perhaps, that is exactly how the artist intended it to appear. Attached to this anthropomorphic image are representations of animals, while the body itself is incised with representations of human faces. In an interpretative essay, Dennis Williams (1994:6-7) submitted that 
the sculptor shows a deliberate "disregard of the natural proportions of the human figure" and, in true African fashion, focuses on "immateriality and spirituality," on the "psychic and organic truth of 1763." In this sense the statue is "mythological and ideal, not naturalistic." He identifies the faces around the statue's body as those of Cuffy's corevolutionaries, and declares that the sculptor initiated a "revolution of vision" requiring the spectators to undergo a similar revolution in order to understand the work. More revolutionary, perhaps, in this interpretation is Williams's view that by breaking out of European artistic conventions, and to some extent even those of Africa and Asia, the sculptor attempts to get Guyanese to break away from the old conventions of the past associated with slavery and colonialism: to be "freed from the self-doubt and self-contempt implanted in our peoples during the 19th [sic] century."

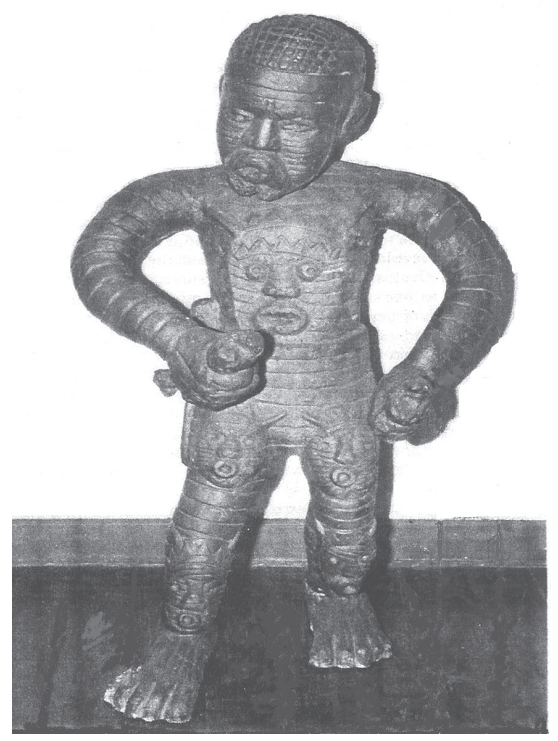

Figure 2. Cuffy Monument

When the statue was first erected many who expected to see a "traditional" human figure found difficulty in associating with it, and even rejected it as being too repulsive for a revolutionary hero. ${ }^{16}$ As noted above, whether initially intended or not, the government did not call the statue Cuffy, but rather "The 1763 Monument," although over time it has become known as the image of Cuffy or the Cuffy Monument. Whatever the truth of the matter

16. See, for instance, "Ugliness Rules," in Guyana Blog, November 20, 2003. http://bloguyana.weblogs.us/archives/003414.html. Accessed April 6, 2005. 
concerning this representation, Cuffy looms tall, not only in statuary form but also in symbolic imaging, at least among his hardcore followers.

Damon has come in for much less attention but he is also gaining recognition as a freedom fighter. His protest or revolt in 1834, though quite different from that of Cuffy in that it was intended to be nonviolent, took place in Essequibo county in response to the inception of the apprenticeship system that the British introduced in their colonies on the very day that they declared emancipation from slavery. As elsewhere, Damon and a number of his colleagues could not reconcile the notion that they were liberated from slavery with the fact that they were compelled by the Apprenticeship Act to work for their overlords on the same plantations or other locations for a period of four to six years, depending on whether they had worked in nonpredial or predial tasks at the time of emancipation. They therefore laid down their tools and engaged in passive forms of resistance. However, according to Hugh "Tommy" Payne (2001), former Guyanese archivist and the writer of the only detailed study of this revolt, the plantocracy, in association with certain members of the colonial government, goaded them into physical confrontation that led to bloodshed, and in the sequel a number of "apprentices" were killed or imprisoned, and Damon was tried and hanged.

For years Damon, or rather his iconic symbol, languished in a graveyard on Devonshire plantation in Anna Regina, Essequibo, represented by a large cross that some persons had tried to maintain; but it had suffered badly from neglect. In 1986 the situation came to public attention when Rovin Deodat published details of the cross and the revolt in a newspaper. ${ }^{17}$ However, it is said that one year earlier the Regional Development Council of Pomeroon-Supenaam had made a decision to erect a monument in honor of Damon (Wiltshire 1994:5). This monument, which the Guyanese Ivor Thom sculpted, was some five-and-a-half meters tall, including its plinth, and was officially unveiled in 1988 at a site now known as Damon's Square (Damon's Park) in Anna Regina. The square has become the focal point for commemorative events, especially those involving struggle and "martyrdom," in Essequibo county. For instance, in October 2003 when Region Two (comprising Pomeroon-Supenaam) commemorated the sugar workers' strike of 1872, which had led to the killing (or "martyrdom," according to one viewpoint) of five Indian workers - Kaulica, Beccaroo, Auckloo, Baldeo, and Maxidally - by the police, among the activities on that occasion was a cultural performance and the laying of wreaths at Damon's Square. ${ }^{18}$

17. Deodat refers to his 1986 article on the subject in "Why is Damon Important in Guyanese History?" Guyana Chronicle, August 8, 1999.

18. "Devonshire Castle Uprising Set an Example," Guyana Chronicle, October 1, 2003. 
Payne feels that the erection of a monument in honor of Damon and the creation of a square only constitute a small part of the just desserts of this freedom fighter. He makes it clear that he wrote his book about the liberation struggles of that individual with "the positive intent of promoting both a public awareness of their existence and the consequential acknowledgement that they constitute a seminal landmark in the panoply of human rights struggle" (Payne 2001:v). Payne explicitly links Damon's struggle with the Colombian advent in the Americas in 1492, which he sees as the first efforts at enslavement of, and resistance by, the indigenous peoples. Thus, implicitly at least, he views Damon's revolt as a continuation of that struggle for freedom. But Payne goes much further, by likening the martyrdom of this insurgent to that of Christ, both of whom gave their lives to set free a multitude of captives. He states that "like Christ, he, Damon, was laying down his life on behalf of his brethren and their vision of a world that they would shape once full freedom came," and notes that Damon himself committed his soul to God through Christ: "I forgive everybody, and I hope Gad sa [sic] forgive me too. I put my trust in Jesus" (Payne 2001:264, 266). Payne takes upon himself the burden of persuading his readers, if not throughout the world at least in Guyana, that "In truth, those '10 Days in August' were of major consequence to the struggle for a world in which freedom and human rights would be legally guaranteed to all: they were as such 'TEN DAYS THAT CHANGED THE WORLD"' (Payne 2001:255). The remarkable aspect of all of this is that before the publication of Payne's work few Caribbean historians knew anything about Damon, and fewer still actually placed him in the gallery of freedom fighters. ${ }^{19}$ The most well-known Guyanese works also had little or nothing to say about this individual. ${ }^{20}$ It may be argued, therefore, that it is the need to find national icons going back to the days of slavery that has spawned the works of such persons as Daly and Payne, who seek to interpret or rewrite aspects of the history of slavery in nationalist terms. ${ }^{21}$

19. The following well-known Caribbean writers on the subject of slavery said nothing about him: Augier, et al. 1960, Williams 1970, Dookhan 1971, Parry, Sherlock \& Maingot 1971, Green 1976, Greenwood \& Hamber 1980, Knight 1990, Rogozinski 1992, Brereton 1998, Ferguson 1998.

20. See, for instance, Daly 1974, McGowan, Rose \& Granger 1998.

21. An important footnote to this discussion is the Muslim (largely Indian) attempt to associate their religion with the 1763 uprising, arguably to create/provide a longer historical foundation for their presence in the country and their contribution to national development. Thus, contrary to all existing documentation on the subject, one group of Muslims opined that "it is also said that in the 1763 rebellion led by Guyanese national hero Cuffy, that [sic] the terms and conditions for peace that Cuffy sent to the Dutch were written in Arabic and this would indicate that there were Muslims among Cuffy's group or that Cuffy himself might have been a Muslim" (see Raymond Chickrie, "Muslims in Guyana." http://www.guyana.org/features/guyanese_muslim.html. Accessed March 28, 
At the same time, it is important to stress that a number of Guyanese of all ethnic and social backgrounds have questioned Daly's interpretation especially of the role of Cuffy in the 1763 revolt. While they admit that he was the leader, they consider it weakness on his part that he sought to divide the country between the slaveholders and his own followers; they also argue that it was his weakness and failure to act decisively that led his chief lieutenants to seek to sideline him. They see his suicide, after hiding the firearms, as an act of betrayal of the rebellion. Paul Nehru Tennassee provides one of the most strident criticisms of what he calls the Daly thesis of the revolt and argues that "while Daly used the Berbice Rebellion of 1763 to rationalize the role of the PNC in the 1950s and 1960s, Forbes Burnham used the distorted interpretation to mould and deepen the ideology of racism" and to give historical credibility to his dictatorial stance on a number of national issues. ${ }^{22}$ In a fictional work, Ruel Johnson has four of his characters from different ethnic groups discussing the fact that Burnham had erected a monument to Cuffy in Georgetown, the nation's capital, while choosing the countryside to erect another one to those Indians who were martyred at Enmore in 1948 (in Birbalsingh 2005).

In spite of such observations and criticisms, some Afro-Guyanese have sought to merge the commemoration of Emancipation Day (Freedom Day) with that of the "martyrdom" of Cuffy, Quamina, and Damon, viewing the whole process as one continuous and heightened struggle against the forces of enslavement and in favor of national liberation. One writer describes some ways in which the event was commemorated in Essequibo in 2002, beginning on Emancipation Eve:

\footnotetext{
Dressed in traditional African styles and holding bottle lamps, the participants sang old-time African folk songs in an atmosphere of joy, peace, love and togetherness as they slowly made their way to Damon's Square, where a grand cultural show was held ... On Thursday, Emancipation Day, scores of persons attended a church service at the Anna Regina Anglican Church and then participated in a cultural street fair at Damon's square. ${ }^{23}$
}

In Georgetown, the annual commemoration is orchestrated much more elaborately. The grounds of the Parliament Buildings (also called Public Buildings), which once housed the court of policy or colonial government, where Damon

2005). For a critical discourse on a similar development in Jamaica see Warner-Lewis 2003:294-316.

22. Paul Tennassee, "The Race Problem 1965-1992: Part III: Who Was the Architect of Independence?" http://www.guyanajournal.com/race3_pt.html. Accessed April 2, 2005. 23. Rajendra Prabhulall, "Colourful Emancipation Celebrations Held in Region Two." Guyana Chronicle, August 13, 2002. 
was hanged, are the scene of the Emancipation Vigil. ${ }^{24}$ This vigil, involving speeches, historical recollections, poetic readings, African drumming, dancing, the pouring out of libations to the ancestral spirits (presumably of the "martyrs") and so on, is a very powerful symbolic representation because it incorporates a number of features of the liberation ethos. First, it testifies to the wrongness or iniquity of the conduct of the enslavers at the highest levels of government, one that should have protected all persons within the society, especially the poor and powerless. Although the colonial government failed to do so, present-day nationalists are interpreting the revolts as early strikes against the colonial administrations, which finally led to independence and local control of parliament.

Second, the ceremonies associate the national government directly with the forces of liberation as defined by the struggles of the "martyrs," and by implication also calls on that government not to fail like its colonial predecessors in protecting the rights of all citizens within the nation. Third, the ceremonies might be interpreted as a warning (or symbolic threat) to the government, now dominated by Indo-Guyanese, that if they do not shape up and recognize those rights, especially as regards the Afro-Guyanese, they might also face revolt and perhaps revolution. Finally, the strong African orientation of the ceremony underlines the African (read Afro-Guyanese) contribution to national liberation and national development.

\section{The POLITICIANS AND THE SPOILS}

Politicians on both sides of the divide, those of the PNC and the PPP, seek to make political capital out of these developments, by identifying with the "revolutionaries" on public occasions. Burnham did so on several occasions, most notably in the months leading up to the inauguration of the Cooperative Republic on February 23, 1970. Speaking at this party's congress in July 1969, he declared, "the significance of the date chosen is well-known ... It is felt that our achievement of independence coupled with our ceasing to be even

24. Damon's Monument was first displayed at his execution site in front of the Parliament Buildings before being taken to its permanent site in Essequibo. On August 1, 2000, Emancipation Day or Freedom Day, Hamilton Green, mayor of Georgetown, turned the sod ceremonially at the execution spot in Georgetown of Quamina and the other "martyrs" of 1823. For Green, the martyrdom of Damon is significant not only for its testimony to his commitment to freedom, but also to the evils of racial bigotry, ethnic cleansing, social inequality, hate, poverty, cultural aggression, ideological arrogance, and oppression in general, some of which Green views as still present, in more muted forms, in presentday Guyana (Linda Rutherford, "Colonial Slavery was the Most Significant, Pervasive Experience: Says Mayor Hamilton Green," Guyana Chronicle, August 3, 2000 and Emancipation Vigil at Public Buildings Tonight, Guyana Chronicle, July 31, 2001). 
fictionally one of Her Majesty's Dominions is the culmination of Cuffy's first thrust at Magdalenenburg [early center of the revolt] in 1663 [i.e. 1763]." ${ }^{25}$

In one of his speeches Burnham blamed Cuffy's followers for his failure to bring the revolution to a successful conclusion. Paul Tennassee quotes him as asserting that "Akara who thought he knew more than Cuffy and should be the leader ... was the architect, along with his Dutch bosses of the physical defeat of our forefathers in their struggles ... [H] e started the division in the ranks; and looking at it from this perspective, was the architect of the physical failure." He goes on to say that Burnham also argued that "physical failure was due chiefly to disunity; to those who thought they knew better, to Akara who may be compared with some of our ultra leftist today;" and (still quoting Burnham) "Cuffy ... had problems with some of his followers, some of them wanted to spend their time dressed in the fineries in which they had seen their mistresses dressed; and some of them complained that Cuffy made them work harder than the white man made them work."26 Burnham's message was clear: disunity among Guyanese and challenges to his leadership were important factors in preventing the country from achieving greater material and social progress, and were even threatening to derail the new revolution that he had started.

Shirley Field-Ridley, a history graduate of the University of the West Indies and a former minister of education under the PNC, also used the occasion in her book titled Co-op Republic to reinforce the view that the 1763 revolt was foundational in the history of the nation's struggle for political, economic, and other forms of redemption. She went on to say that every nation and generation has to interpret its present and carve its future from the relics of its past and "in this process, so well begun, we have identified Cuffy, whose memory was almost obliterated as our national hero ... [H]e, in fact, was concerned with ending a system which had been dehumanizing his followers and replacing it with what he saw to be disciplined freedom."27

Under Burnham, Cuffy was also viewed as the ideologue of the new revolution that the president claimed was unfolding. To promote this transformation, the government laid the foundation stone for the Cuffy Ideological Institute in 1974 and started instruction there on August 1, 1977 (Emancipation Day). ${ }^{28}$ Daly (1970:97) had pointed the way to the establish-

25. "Towards a Co-operative Republic": Address by the Hon. L.F.S. Burnham to the 12th Congress of the People's National Congress. Georgetown 1969:11; see also Burnham 1970:68-69, 156.

26. Paul Tennassee, “The Race Problem 1965-1992: Part II: The Post Independence Era: Alienation and Insurrection." http://www.guyanajournal.com/race2_pt.html. Accessed April 2, 2005.

27. Quoted in Tennassee, "The Race Problem 1965-1992: Part II."

28. Economic Liberation Through Socialism, Leader's Address: 2nd Biennial Congress of the P.N.C., August 12-20, 1997, by the Office of the Prime Minister, Georgetown, Guyana, 1977. 
ment of such an institute as the main pedagogical instrument to promote the cultural revolution that the new era would spawn: "The cultural revolution needs ... a spiritual home - an intellectual and artistic centre as the focal point for generating cultural activity. Such a centre should be set up by government and named the Institute of Guyana."

While the PPP has used the image of Cuffy and of the 1763 uprising much more discreetly than other groups, it has recognized the need to associate with some "popular" interpretations of the "revolution." Senior members of the PPP are often present on ceremonial occasions honoring the "martyrs." In 1988 Cheddi Jagan and Moses Nagamootoo produced a statement on the hundred and fiftieth anniversary of emancipation in which they declared that "in the face of great odds [,] superior forces and arms, our early revolutionaries proved they could not easily be intimidated. Leaders such as Cuffy in Berbice, Quamina in Demerara and Damon in Essequibo laid down their lives in heroic struggles for freedom." 29 Moses Nagamootoo, ${ }^{30}$ in another publication, produced one of the most articulate pieces of writing for the popular press that we have come across. However, at that time he was no longer a member of the PPP cabinet, but an attorney-at-law in private practice. He traced the history of Black struggles during slavery in Guiana and other parts of the Americas and referred to Cuffy and Quamina as "our early revolutionaries" who laid the foundation for a free Guyana. He concluded by saying, "All the more [reason] why Emancipation should be a sweet word on the lips of every Guyanese of African ancestry." He also linked these struggles with those of the later struggles of Indian indentured people in the country, and declared that indentureship was a euphemism for "wage-slavery."

The PPP has used Damon's Square in Essequibo for political purposes. During the 2001 electoral campaign the main PPP leaders, President Bharrat Jagdeo and Prime Minister (and first Vice President) Samuel Hinds, addressed a gathering there. ${ }^{31}$ Jagdeo has attended a number of Emancipation Day events, mixed with the celebrants, and spoken positively about the value of maintaining Afro-Guyanese cultural expressions, as also those of all other ethnic groups in the country. ${ }^{32}$ On the occasion of the celebrations in 2002 he regurgitated the myth that the Berbice revolution was a success (even if temporarily) and that it pointed the way to the Haitian Revolution: "Guyana holds the honor in the history of this hemisphere of holding the first suc-

29. Eternal Glory to Our Ancestors, by the People's Progressive Party, Georgetown, Guyana, 1989.

30. "Fruit of African Resistance and Sacrifices." Guyana Chronicle, August 3, 2003.

31. "Elections Campaign Tempo Steps Up: Rallies Continue, GAP-WPA Launches Manifesto," Guyana Chronicle, February 18, 2001.

32. "Preservation of Every Ethnic Culture Vital to Guyana's Society: President Jagdeo Joins National Park Emancipation Celebrations," Daily News, August 1, 2003. 
cessful slave rebellion which overthrew the Dutch and were in control of [Berbice for] over a year before it was brutally and ruthlessly smashed. Our ancestors' courageous rebellion was the precursor for the Haitian revolution which established the first free state led by black people in 1801." 33 Hinds has also customarily addressed the groups gathered at the commemorative ceremonies on the lawns of the Parliament Buildings on the eve of Emancipation Day. In 2002 he accepted an impromptu invitation from the head of the National Emancipation Trust (a private organization spearheading the event), to sit as one of the traditional elders during that event and to participate actively in the libation ceremony. ${ }^{34}$

In a situation of racial tension in the country, some Afro-Guyanese question the sincerity of the identification of the Indian political leaders with the Afro-Guyanese national celebrations and other landmarks in Afro-Guyanese history. (Of course, the same comment might be made about the AfroGuyanese commitment to commemorating Indian Arrival Day on May 5, 1838 - another national holiday - and other Indian secular and religious events on the national calendar.) Periodically, certain ambivalent statements, such as the one that Cheddi Jagan made on Independence Day, May 26, 1993, following his accession to power on October 5, 1992, seem to add some conviction to their viewpoint. On that occasion Jagan declared:

\footnotetext{
Let us remember our own heroes. For Cuffy, a monument has already been built. Let us also honor the real heroes, not those who signed the Proclamation but those who struggled before May 26, 1966 to make Independence a reality - those who launched the Political Affairs Committee in 1946 ... [T] is a nexus between Cuffy in 1763, 1946, 1966 and October 5th $1992 .{ }^{35}$
}

This statement was clearly aimed at excluding the PNC leaders from nationalhero status. It declared that the connections between Cuffy's "revolution" in 1763 and the post-World War II struggle for freedom were the formation of the political group that Cheddi Jagan founded in 1946, the attainment of independence in 1966, and his accession to power for the third time in 1992. He deliberately excluded 1970, the date of the declaration of the Cooperative Republic, as one of the milestones in the nation's history, though he was clearly not a monarchist. While that part of his statement about honoring "the real heroes" could be interpreted by some persons as a verbal slip that

33. Guyana Monthly Update, August 2002. A Monthly Publication of the Embassy of Guyana, in Washington DC.

34. Linda Rutherford, "Prime Minister Creates Stir at Libation Ceremony," Guyana Chronicle, August 2, 2002.

35. Year of Rediscovery: Souvenir Magazine of Guyana's Independence Celebrations '93, by the Ministry of Information, 1993. 
suggests that Cuffy was not a real hero, none of his other comments seem to justify such an interpretation.

Many Afro-Guyanese express concern about the booklet that Janet Jagan, the wife of Cheddi Jagan, produced in 1995. In that work, titled Children's Stories of Guyana's Freedom Struggles, she makes no mention whatsoever of Cuffy, or indeed any of the "trinity" of Black freedom fighters. Instead, in the first chapter, titled "The Legend of the Enmore Martyrs" (1948), her heroes are the Indo-Guyanese Rambarran, Surujballi, Harry Jug, Pooran, and Lala Bagee. She places their names in italics and admonishes her readers to "remember their names well." The following chapter, titled "A Children's Story of Independence," is about Cheddi Jagan (whose name was also placed in italics in the previous chapter) and the PPP's political struggles. Her third chapter focuses on "Kowsillia - A Brave Woman Who Gave Her Life In the Freedom Struggles," and deals with an Indian woman by that name, also called Alice (neither of whose two names is in italics in the text), who died in 1964 during a strike on plantation Leonora, when strike-breakers drove a tractor through the midst of the strikers. The next chapter deals with Michael Forde (not in italics in the text), a Black man to whom she referred as "a true hero," who died in a bomb blast at the PPP's bookshop in 1964. The final chapter, which deals with the PPP's attempts at "winning back democracy," chastises the PNC for political nepotism, electoral fraud that led to the deaths of Jagan Remessar and Jack Bhola Nauth (whose names are italicized), and admonishes readers, "remember their names for they were martyrs in the freedom struggle." Walter Rodney's assassination in 1980 is also mentioned in this chapter, but his name is not italicized nor is he declared a martyr. ${ }^{36}$

It seems clear that Janet Jagan, if not the other leaders of the PPP, sought through this booklet to reduce the emphasis that the PNC placed on their Black revolutionaries and promote Indian revolutionaries and martyrs. This article does not seek to justify the PPP or PNC in placing their "martyrs" in specific positions in the iconography depicting the nation's freedom struggles. Rather, it seeks to show (in part) how the legacy of slavery was promoted or muted, depending on the particular party in power. Thus, the analysis of Janet Jagan's booklet should not be seen as a criticism of the PPP government, but rather as one of the realities of the multiracial society that constitutes Guyana. However, this also helps to throw into relief the tensions in discourses on important national issues. Afro-Guyanese have increasingly had to share not only political space but also cultural heritage and festival days with Indo-Guyanese.

At a more concrete level, both the Cuffy and Damon monuments were neglected badly, especially during the early years of the PPP regime in the

36. See especially pages 4 and 19 of this work. In it the author refers to Kowsillia, Forde, and Rodney as heroes but not as martyrs in the struggle for freedom. 
1990s. Whether this was deliberate or not remains a moot point. However, the reality is that the Cuffy Monument was rehabilitated in 1999 (and since then maintained) largely through the initiative of Afro-Guyanese, led by the Movement for Economic Empowerment, and with valuable assistance from the African Cultural and Development Association and other Afro-Guyanese organizations. Some Indo-Guyanese also provided assistance. It was also alleged that government information booklets on the Cuffy Monument that had been available during the PNC regime were no longer being produced (Dow 2000-2001:40). In 2001-2002 the Damon Monument was refurbished through the joint efforts of the National Trust of Guyana (a government organization), the Ministry of Tourism, Industry and Commerce, and the Organization of American States, as part of a larger effort to identify and preserve sites of cultural and historical significance in the country. ${ }^{37}$ Arguably, this monument, more than any other in the country, has been a meeting point of various ethnic groups for commemorative events involving struggles against oppression under colonialism.

\section{NONGOVERNMENTAL ORGANIZATIONS AND PRIVATE INDIVIDUALS}

As intimated above, it is not only governmental organizations but also private ones that have emerged as important vehicles for commemorating the resistance efforts of the enslaved (and wider African cultural activities). Such organizations have existed since the early postemancipation period, but since independence a growing number of them have emerged. Among the current ones are the African Society for Cultural Relations with Independent Africa (ASCRIA), founded in 1968. There are also the Pan African Movement (Guyana Branch), the African Cultural and Development Association, the National Emancipation Trust, the Kingdom of Manumitted Africa (founded originally as the Descendants of Africa), and the House of Nyabinghi (Guyana Branch). ASCRIA is the most well known and arguably most respected of these organizations. Under its leader Eusi Kwayana (formerly known as Sydney King), who was once a member of both the PPP and the PNC, it has played a seminal role in the development of a Black or African diaspora consciousness in the country. The main activity of the National Emancipation Trust, under its leader Lorri Alexander, has been the organization of the Emancipation vigil, which it has succeeded quite well in doing. The Trust has managed to bring together politicians from the various political parties in the country both as spectators and participants (though the PPP is usually represented by Samuel Hinds, the Black prime minister). It

37. Wiltshire 1994:5; “The Damon Monument," Daily Chronicle, November 3, 2002. See also Thompson 2002:336-45. 
has also engaged in an annual Miss Guyana African Heritage Beauty Pageant since $1994 .{ }^{38}$

The African Cultural and Development Association has been involved since 1995 in the organization of Emancipation Day celebrations at the National Park in Georgetown, where thousands attend annually. ${ }^{39}$ The 2002 celebrations were a colorful spectacle of African dress, as Linda Rutherford notes: "Indeed, looking down from the stage at the swell of humanity gathered on the tarmac to savour the cultural presentations, one could have easily been misled into believing that they were in a country in Africa." 40 Participants at the celebrations came from Suriname, Cuba, Colombia, Brazil, and as far away as South Africa. Events included a church service, storytelling, facepainting, a craft exhibition, drumming, dancing, singing, and a wide range of sports. ${ }^{41}$ The association is also the main local organizer of African Holocaust Day, commemorated annually on October 12, the date of Columbus's advent in the Americas. ${ }^{42}$ The events usually include a libation ceremony, invoking the ancestral spirits, on the Atlantic coastline. Bishop Atu Balon Gemu, who presided over the proceedings in 2003, explained that "libation is a ceremonial outpouring and an exercise of atonement with our ancestors. This exercise is a sacred act; it helps us realise our kinship with our ancestors and must be done as the occasion warrants." Participants were provided with the opportunity of washing themselves, symbolically cleansing their spirits, in order to be able to pay acceptable tribute to their forebears who perished during the transatlantic crossing. Among the invited overseas guests in 2003 were Maulana Alhassan Bashir Annan, a visiting Ghanaian missionary of the Ahmadiyya Muslim Jamaat, who was the guest speaker on the occasion; Shabaka Kambon of the Emancipation Support Committee of Trinidad and Tobago; and David Commissiong, director of the Barbadian government's Commission for Pan-African Affairs. ${ }^{43}$

The Kingdom of Manumitted Africa was established much more recently and is less well known than the other groups, but seems to be gaining greater recognition, at least among Afro-Guyanese. In March 2004 it held a ceremony commemorating "African Martyrs' Day" in honor of Cuffy and 209 of his fallen comrades. The organizers made it clear that the event was intended to

38. Rutherford, "Prime Minister Creates Stir," 2002; "Emancipation Vigil at Public Buildings Tonight," Guyana Chronicle, July 31, 2001; Rutherford 2002-2003.

39. On the recognition and celebration of Emancipation Day in Trinidad and Jamaica, see Brereton 1983:69-83; Henry 2003:73; Higman 1979:55-74.

40. Rutherford, "Prime Minister Creates Stir," 2002.

41. Rutherford, "Prime Minister Creates Stir," 2002.

42. Guyana seems to be one of the few countries in which this day is commemorated elaborately.

43. Rutherford, “Colourful African Holocaust Day,” 2002; Never Again! 2003. 
ensure that the government and wider society recognized the contribution of Africans to the country's development. ${ }^{44}$

Apart from Guyana-specific events, the various organizations mentioned above are collectively involved in commemorating/remembering international events relating to the African Diaspora, such as African Civilization Day, Black History Month, African Holocaust Day, and the UNESCO Slave Route Project. These activities are carefully crafted into the local ones, stressing freedom, liberation, and emancipation from the residual legacies of enslavement.

Outside the organizations already discussed, a much larger number of Guyanese view slavery and various dates and events relating to it as important matters for public discourse. One of the most important of these occasions is Emancipation Day, which a number of them have come to view not only as a day of celebration, commemoration, and emphasis on "things African" through music, song, dance, cuisine, and so on, but also a time of reflection, of assessing what Afro-Guyanese have achieved and what remains to be achieved. In 2000 David Hinds, a Guyanese born in Buxton, an assistant professor at the Arizona State University, and a regular writer to the popular press, wrote:

This Emancipation anniversary is a good time to start correcting some of those wrongs. The African in Guyana must begin the task of self-love today. He must begin sending his children to school again. He must begin to engage in economic activity both individually and collectively. He must support Black endeavors, not out of spite against another race, but out of genuine intra-group solidarity. He must join African cultural organizations. ${ }^{45}$

Prime Minister Hinds voiced somewhat similar sentiments on a similar occasion two years later. ${ }^{46}$

It is also largely nongovernmental organizations and private individuals that campaign for reparations. As in other areas of the Black diaspora, reparations by the former colonial powers have become a burning issue among the more Black-conscious groups within Guyanese society, though much of the discussion is linked with the international discourse on the subject. For instance, a local newspaper, the Guyana Chronicle, printed a letter to the editor by Rakesh Rampertab, ${ }^{47}$ taking to task certain U.S. senators who campaigned for reparations for Jewish Holocaust survivors but not for Blacks. In

44. "Cuffy and 209 Others Remembered," Daily Bulletin, Guyana Government Information Agency, March 31, 2004. The organizers promised to hold an annual ceremony in honor of the "martyrs" and did so again in March 2005.

45. Hinds, "Emancipation and the African-Guyanese Reality," 2000.

46. Rutherford, "Prime Minister Creates Stir," 2002.

47. "Enough is Enough," Guyana Chronicle, September 15, 2001. 
2002, on the occasion of African Holocaust Day, Violet Jean-Baptiste spoke to a gathering in Georgetown about the significance of the occasion, and in closing stated, "I want to urge you as you leave here today, that you embark on a campaign within your group; within your homes; within your families; even at the street corners, to bring to mind this great tragedy, and to join the growing movement and add your voices to the call for reparations that's going out globally." 48 Colin Moore, a Guyanese lawyer now living in New York, is among those who argue that the enslavers received reparations for the loss of their enslaved charges but the latter did not receive anything but elemental freedom, and therefore their descendants have a right to demand reparations. ${ }^{49}$

Guyanese generally realize that reparations can only be achieved through global rather than local agitation, though Hamilton Green once asked President Jagdeo not to request debt forgiveness by former European colonial powers but to "do the dignified thing and discuss reparation." ${ }^{50}$ Nevertheless, many AfroGuyanese are not convinced that this is an important issue in the minds of the Indian-dominated PPP government, especially since there are no (or, at least, only feeble) voices calling for reparations for the Indian indentured workers who went to Guyana and elsewhere in the immediate postslavery period.

It was out of the womb of ASCRIA that the famous Yoruba Singers were born in 1971. They began by focusing mainly on African-style folk songs but widened their repertoire to include reggae and other Caribbean musical forms. Garbed in traditional African costumes, they have traveled widely around the world and performed on a number of important occasions in the Caribbean, United States, Canada, Britain, and elsewhere. They performed at the Ringbang Millennium Concert in Tobago on December 31, 1999, which the British Broadcasting Company transmitted to about 2.5 billion viewers worldwide. They are said to have over 300 songs to their credit and numerous music albums. The Guyana government has awarded them the Medal of Service for their outstanding contribution to the country's musical culture. ${ }^{51}$

The Burnham government placed strong emphasis not only on the wearing of African-style clothes and accessories, but also on establishing meaningful relations with the African continent. It was well known that he held great admiration for Kwame Nkrumah, incontestably the greatest pan-Africanist of the early postcolonial era. While not actually articulated by Burnham, as

48. Rutherford, “At Colourful African Holocaust Day,” October 13, 2002.

49. Colin A. Moore, "Emancipation - A Dream Deferred." http://www.guyanajournal. com/Eman_CM.html. Accessed April 18, 2005.

50. "Colonial Slavery was the Most Significant, Pervasive Experience - Says Mayor Hamilton Green," Guyana Chronicle, August 3, 2000.

51. Kross Kolor Records, Yoruba Singers. http://www.krosskolor.com/yoruba_bio.htm. Accessed April 28, 2005. 
Nkrumah did, it seems that Marcus Garvey's Universal Negro Improvement Association also impacted heavily on him. Both Nkrumah and Burnham were deeply involved in the Non-Aligned Movement. The Burnham government erected monuments in the country to the African Liberation Movement and the Non-Aligned Movement. ${ }^{52}$

February and August are the two months in which special emphasis in the country is placed on "things African." February is the date of the Berbice revolt (or February Revolution) and the inauguration of the Cooperative Republic. That month is also Black History Month (African History Month) universally and especially in the United States. August is emancipation month. During these periods lectures, celebrations, ceremonies, festivals, arts and crafts, and so on emphasize the achievement of Black peoples locally, in Africa, and in the wider diaspora. However, arguably the vast majority of Afro-Guyanese do not embrace these specific "African" or "Africanderived" activities owing to class biases and socialization that continue to point to "things European" as the expression of high culture. ${ }^{53}$ Still less do the Indians and other, smaller groups spend time, money, and energy on such occasions, though they do relish the bank holidays on Emancipation Day and Republic Day to relax, go picnicking, and so on.

\section{EDUCATION AND LIBERATION}

In Guyana, as in most countries connected with the slave trade and slavery, the true significance of the "African Holocaust" remains largely unknown, or only vaguely known among their rank-and-file members. Richard Price (2001:60-61) rightly declares that

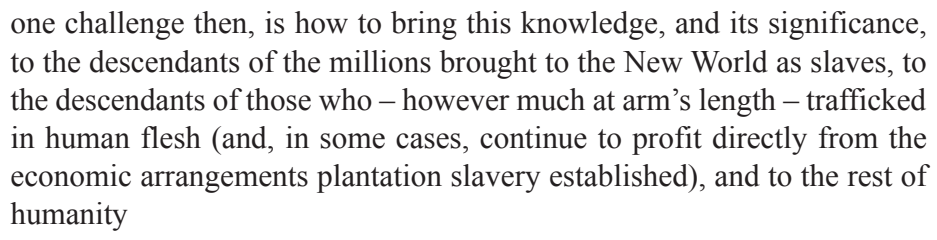

and again, "my thoughts on memorials run less to bricks and mortar than to knowledge and its diffusion. What if we tried to make sure that every schoolchild in Europe, the Americas and Africa is exposed as fully as pos-

52. The National Trust of Guyana, "National Monuments." http://www.nationaltrust. gov.gy/natmonuments.html. Accesses April 13, 2005.

53. Al Craighton, "African Heritage in Guyana." http://www.guyanaunderseige.com/Cultural/African heritage GT.htm. Accessed April 25, 2005. 
sible to the history of slavery and the complexity of its legacy?" Price, as many other writers, view such knowledge as essential to our understanding of the present and as a guide to the future, in terms of Black self-esteem, cultural heritage, ${ }^{54}$ race relations, international relations, and so on. For instance, Flavio dos Santos Gomes (2001:81) asserts that "discourse about black ethnology in Brazil was partially constructed using the quilombos [Maroon settlements] as a paradigm."

The close association of the acquisition of knowledge or (re)education with true freedom or liberation appears frequently in works dealing with the legacies of slavery in Guyana, and Walter Rodney becomes the chief icon of liberation through such a process. On the twentieth anniversary of his assassination, the Working People's Alliance, of which he was a member, referred to Bob Marley's declamations against mental slavery, and called upon all Guyanese to honor Rodney, their martyr and "prophet of self-emancipation." They should "apply this Rodneyite principle of self-emancipation to all the debilitating circumstances, diseases, economic, gender, cultural and spiritual influences which limit the generations in growth and healthy development into a self-respecting, human family in which all parts accept and respect one another." 55 Rodney's How Europe Underdeveloped Africa (1972) and The Groundings With My Brothers (1969) 56 are the two works cited most often by the "liberation school"; but works by other Guyanese (and Black African and diaspora) writers are also mentioned. Among these is the pioneering work of Norman E. Cameron, titled The Evolution of the Negro (1929 and 1931). All the main Afro-Guyanese organizations have some sort of educational program, ranging from instruction in "academic" subjects to handicraft, food preparation, farming, and general discussions on African history and matters relating to Africa and the African diaspora. The African Cultural and Development Association has a youth arm called the Center of Learning and Afrocentric Orientation.

\section{CONCLUSION}

In a largely uniracial society it is much easier than in a multiracial one to develop national symbols that are likely to be accepted by the vast majority. The situation becomes even more difficult when symbols are developed

54. Sansone (2001:86) defines heritage as "the preservation of the past for the sake of the future of the nation."

55. WPA Statement on the 20th Anniversary of Walter Rodney's Assassination. http:// www.guyanacaribbeanpolitics.com/wpa/wpa_statement21.html. Accessed March 29, 2005.

56. For a detailed study of Rodney and his writings see Lewis 1998. 
in a society where two large ethnic groups are competing for precedence on nearly every front: political, economic, religious, cultural, and so forth. David Trotman (2006) has demonstrated the accuracy of this observation in the case of Trinidad. Guyana has basically the same ethnic configuration as Trinidad. However, while much of the symbolism developed in that country was done through private agency, in Guyana the national government under Burnham took the leading role.

Of course, within the wider context of the Americas Burnham's initiative, though perhaps somewhat extreme in comparison to what other countries have done, falls within the broad pattern of attempts to elevate "slave rebels" to national hero status. Burnham could therefore count on strong support at the regional and hemispheric levels for his initiative in this respect. East Indians, though constituting significant elements in the Guyanese (and Trinidadian) population, are a tiny minority in the Americas as a whole, and their struggles under indentureship are even less known than those of the Africans. This is why, perhaps, on the issue of reparations for the sufferings of their ancestors, they have been virtually silent.

Some may argue, therefore, that in order to appear "progressive" in the face of the recent international resurrection of the slavery past (an activity involving Africa, North America, Latin America, Europe, and the Caribbean subregion), the East Indians in Guyana have embraced to a greater or lesser extent the establishment of monuments to slave heroes. However, it is equally plausible to argue that most East Indians in that country have no real problem with those slaves who have been elevated to national hero status, and that what concerned them is the almost complete neglect by the (predominantly Black) PNC regime to give due respect to Indians whose ancestors deserved a place in the national pantheon of "gods."

\section{REFERENCES}

ABRAMS, OVID, 1998. Metegee: The History and Culture of Guyana. Queens Village NY: Ashanti Books.

AUGIER, F.R., et al., 1960. The Making of the West Indies. Essex, U.K.: Longmans.

BARTELS, DENNIS, 1977. Class Conflict and Racist Ideology in the Formation of Modern Guyanese Society. Canadian Review of Sociology and Anthropology 14:396-405.

BIRbalsingh, Frank, 2005. Review of Ruel Johnson's Ariadne and Other Stories. Trinidad and Tobago Review 27:26.

BLAKELY, ALLISON, 2001. Remembering Slavery in the United States. In Gert Oostindie (ed.), Facing Up to the Past: Perspectives on the Commemoration of Slavery from Africa, the Americas and Europe. Kingston: Ian Randle, pp. 102-8. 
BRERETON, BRIDGET, 1983. The Birthday of Our Race: A Social History of Emancipation Day in Trinidad, 1838-88. In B.W. Higman (ed.), Trade, Government and Society in Caribbean History 1700-1920: Essays Presented to Douglas Hall. Kingston: Heinemann, pp. 69-83.

- 1998. A Social History of Emancipation Day in the British Caribbean: The First Fifty Years. In Hilary McD Beckles (ed.), Inside Slavery: Process and Legacy in the Caribbean Experience. Kingston: Canoe Press, pp. 79-95.

BurnhaM, ForBeS, 1970. A Destiny to Mould. London: Longmans.

CAmeron, Norman E., 1929. The Evolution of the Negro. Vol. 1. Georgetown: Argosy.

-, 1934. The Education of the Negro. Vol. 2. Georgetown: Argosy.

DALY, P.H., 1970. Revolution to Republic. Georgetown: Daily Chronicle.

DALY, VERE T., 1974. The Making of Guyana. London: Macmillan.

DesPres, LeO A., 1969. Differential Adaptations and Micro-Cultural Evolution in Guyana. Southwestern Journal of Anthropology 25:14-44.

DOOKHAN, ISAAC, 1971. A Pre-Emancipation History of the West Indies. London: Collins.

Dow, MELISSA, 2000-2001. Save the National Monument. Emancipation 1(8):40.

Drescher, SEYMOUR, 2001. Commemorating Slavery and Abolition in the United States of America. In Gert Oostindie (ed.), Facing Up to the Past: Perspectives on the Commemoration of Slavery from Africa, the Americas and Europe. Kingston: Ian Randle, pp. 109-12.

FERGUSOn, JAMES, 1998. The Story of the Caribbean People. Kingston: Ian Randle.

GIBSON, KEAN, 2003. The Cycle of Racial Oppression in Guyana. New York: University Press of America.

GREen, William A., 1976. British Slave Emancipation: The Sugar Colonies and the Great Experiment 1830-1865. Oxford: Clarendon Press.

Greenwood, R. \& S. HAMBER, 1980. Caribbean Certificate History 2: Emancipation to Emigration. London: Macmillan Caribbean.

HENRY, FRANCES, 2003. Reclaiming African Religions in Trinidad: The Socio-Political Legitimation of the Orisha and Spiritual Baptist Faiths. Kingston: University of the West Indies Press.

Higman, B.W., 1979. Slavery Remembered: The Celebration of Emancipation in Jamaica. Journal of Caribbean History 12:55-74.

JAGAN, JANET, 1995. Children's Stories of Guyana's Freedom Struggles. Georgetown: New Guyana Co. 
KNIGHT, FRANKLIN W., 1990. The Caribbean: The Genesis of a Fragmented Nationalism. Oxford: Oxford University Press. [Orig. 1978.]

KWAYANA, EUSI, 1999-2000. Review of Themes in African Guyanese History, McGowan, Winston F., James G. Rose \& David A. Granger (eds.). Emancipation 7:16-17.

LEWIS, RUPERT CHARLES, 1998. Walter Rodney's Intellectual and Political Thought. Kingston: The Press - University of the West Indies.

MCGOWAN, Winston F., JAMES G. ROSE \& DAVID A. GRANGER (eds.), 1998. Themes in African-Guyanese History. Georgetown: Free Press.

MOORE, ROBERT J., 1999. Colonial Images of Blacks and Indians in Nineteenth Century Guyana. In Bridget Brereton \& Kevin A. Yelvington (eds.), The Colonial Caribbean in Transition: Essays on Postemancipation Social and Cultural History. Gainesville: University of Florida Press, pp. 126-58.

PARRY, J.H., P.M. SHERLOCK \& A.P. MAINGOT, 1971. A Short History of the West Indies. London: Macmillan.

Payne, Hugh "Tommy," 2001. 10 Days in August 1834: 10 Days that Changed the World. Brooklyn NY: Caribbean Diaspora Press.

PRICE, RICHARD, 2001. Monuments and Silent Screamings: A View from Martinique. In Gert Oostindie (ed.), Facing up to the Past: Perspectives on the Commemoration of Slavery from Africa, the Americas and Europe. Kingston: Ian Randle, pp. 58-62.

RoDNEy, WALTER, 1969. The Groundings with My Brothers. London: Bogle L'Ouverture Publications.

—, 1972. How Europe Underdeveloped Africa. London: Bogle L'Ouverture Publications.

RogOZINSKI, JAN, 1992. A Brief History of the Caribbean: From the Arawak and the Carib to the Present. New York: Facts on File.

RUTHERFORD, LINDA, 2002-3003. African Heritage Pageants. Emancipation 1(10):6465 .

SANCHO, T. ANSON, [1966]. Highlights of Guyanese History. Georgetown: n.p.

SANSONE, LIVIO, 2001. Remembering Slavery from Nearby: Heritage Brazilian Style. In Gert Oostindie (ed.), Facing Up to the Past: Perspectives on the Commemoration of Slavery from Africa, the Americas and Europe. Kingston: Ian Randle, pp. 83-89.

SANTOS GOMES, FlÁVIO DOS, 2001. The Legacy of Slavery and Social Relations in Brazil. In Gert Oostindie (ed.), Perspectives on the Commemoration of Slavery from Africa, the Americas and Europe. Kingston: Ian Randle, pp. 75-82.

Thomas, Deborah A., 2004. Modern Blackness: Nationalism, Globalization, and the Politics of Culture in Jamaica. Durham NC: Duke University Press.

THOMPSON, ALVIN O., 1987. Colonialism and Underdevelopment in Guyana 1580-1803. Bridgetown, Barbados: Carib Research \& Publications. 
- 1997. The Haunting Past: Politics, Economic and Race in Caribbean Life. Kingston: Ian Randle.

—, 2002. Review of Hugh "Tommy" Payne's 10 Days in August 1834. Journal of Caribbean History 36:336-45.

—, 2006. Flight to Freedom: African Runaways and Maroons in the Americas. Kingston: University of the West Indies Press.

TINKER, HUGH H., 1974. A New System of Slavery: The Export of Indian Labor Overseas 1830-1920. London: Oxford University Press.

TROTMAn, DAVID, 2006. Public History, Landmarks and Decolonization in Trinidad. The Journal of Caribbean History 40:39-63.

WARNER-LEWIS, MAUREEN, 2003. Jamaica's Muslim Past: Misrepresentations. Journal of Caribbean History 37:294-316.

WiLliams, BRACKETTE F., 1991. Stains on My Name, War in My Veins: Guyana and the Politics of Cultural Struggle. Durham NC: Duke University Press.

WILLIAMS, DENNIS, 1994. The 1763 Monument. Emancipation 2:6-7.

WILliams, ERIC, 1970. From Columbus to Castro: The History of the Caribbean, 14921969. London: André Deutsch.

WILTSHIRE, SYBIL, 1994. Damon's Monument. Emancipation 2:5.

\author{
ALVIN O. THOMPSON \\ Department of History and Philosophy \\ University of the West Indies \\ Cave Hill Campus \\ Barbados \\ <thompsonaot@yahoo.co.uk>
}

